\title{
Turkey's Entrance to International Education: The Case of Turkish Maarif Foundation
}

\author{
BIIROL AKGÜN* and MEHMET ÖZKAN** \\ * Turkish Maarif Foundation, Turkey \\ ORCID No: 0000-0002-9654-105X \\ ** Maarif Foundation, United States \\ ORCID No: 0000-0001-5256-9790
}

\begin{abstract}
The Turkish Maarif Foundation (TMF) is the most recent state-led institution to promote Turkey's cultural diplomacy and soft power. Since 2016, it has contributed to the transformation of international education with a Turkey-centric perspective through its schools, dormitories, and universities in more than 40 countries. Through its educational fairs and student guidance from abroad to Turkey, TMF has the potential to play a coordinating role in Ankara's educational outreach to the world. Similarly, TMF's activities should be seen to advance the UN Millennium Development Goals in education, especially in LDC countries. This article contextualizes the Turkish Maarif Foundation in Turkish foreign and domestic policy and outlines a vision through evaluating its activities over the past three years.
\end{abstract}

Keywords: Turkey, International Education, Soft Power, Turkish Maarif Foundation

Insight Turkey 2020

Vol. 22 / No. 1 / pp. 59-70 


\section{Introduction}

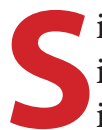
ince 2010, Turkey has increasingly been one of the centers of international education. Turkish scholarships, Diyanet Foundation scholarships and increasing internationalization of Turkish universities has not only moved Turkey forward as a new hub for education but has also brought new challenges. Internationalization has brought complex issues to be tackled, new problems and most importantly adaptation of thousands of new students into Turkish academia. As the Turkish education system has internationalized, an institution to manage education on behalf of Turkey abroad has come to the fore as a necessity.

While internationally Turkey was advancing in the field of education, internationalization of Turkey-centric education was lacking. Turkish Maarif ${ }^{1}$ Foundation (TMF) was founded in June 2016 by the Turkish Grand National Assembly with the positive support of all political parties, including the main opposition Republican People's Party (CHP) as a national foundation. TMF was tasked to open schools, universities, dormitories and all activities related to education outside of Turkey working closely with Turkish embassies and other Turkish institutions to promote Turkish education abroad.

Turkey's entrance into the field of international education is a culmination of two developments. Firstly, Turkey's own domestic transformation since 2002 at political, social, and economic levels has widened the arena, necessity and urgency of re-constructing Ankara's soft power policies, including in the field of education. Secondly, the rise of the non-western world, not only in global politics but also in transforming international education through scholarships, student mobilization and competition so providing new hubs for education, has created new opportunities for Turkey.

Coupled with these two developments, was the attempted military coup of July 15, 2016, by the Fetullah Terrorist Organization (FETÖ), ${ }^{2}$ whose internationalization was mostly based on opening so-called Turkish schools all over the world. This event urged Turkey to re-claim its own domain, mostly controlled by FETÖ, in international education and so in this context the Turkish Maarif Foundation was established. This article aims to contextualize TMF as a new but strong soft power element of Turkish foreign policy and its meaning for Turkey's entrance to international education and beyond.

\section{Transformation of International Education}

Internationally recognized degrees or diplomas in the non-western world have always been a prestige both for students and families. Such an education not only meant that graduates stood out in the community, but also opened new horizons for their work and careers. This has created an increasing demand for international education in many parts of the world ${ }^{3}$, 
creating a growth market for organizations, countries and actors involved in educational goods and services.

According to the International School Research report, in 2013,

International schools cater for the richest $5 \%$ of the non-English speaking world. A typical international school teaches wholly or partly in English, is independent and is located in a non-English speaking country. Roughly $20 \%$ of students in international schools are from expatriate families but the biggest group, and the most rapidly expanding, comes from the wealthy local population. The demand for English-medium schools (British, American, International and bilingual) is increasing dramatically in many parts of the world. ${ }^{4}$

International education is no longer a movement from south to north, as was the case several decades ago. In the past, most of the south-south movement of students used to be between the Soviet Union and its allies during the cold war; however, this had not substantially challenged the perceptional superiority of western education in terms of attracting the best brains to Europe and the United States.

Since the mid-2000s, China has entered the field of international education as an important actor both sending students abroad and receiving them with full scholarship from all over the world. In the last decade, Brazil, India, South Africa, South Ko-

\section{With the establishment of the} Turkish Maarif Foundation, Turkey has embarked on a more organized and serious endeavor in the field of international education as a new actor

rea, and many other pivotal middle powers joined this development. In 2016, China sent abroad 801,000 students, and received 440,000 students. ${ }^{5}$ Similarly India received 45,424 students in $2016^{6}$ and sent 752,725 students abroad, mostly to the U.S.

Transformation of international education of course was not only at university level. Many countries from the non-western world have also supported opening high schools in different parts of the world. The easy movement of teachers and academics from west to non-western countries, either for economic or other reasons, has increased the capacity of those high schools and university to compete with existing ones in the west. Now this is going further with more non-western countries, including Turkey, also entering the field of international education.

Ankara has opened and administered schools outside of Turkey through the Ministry of Education since the 1980s, however, they were very limited embassy schools, serving the needs of Turkish citizens. Opened 
In the last decade, Turkey's soft power activities have expanded from development aid to civil society

engagement all over the world ish Airlines and many other institutions have expanded their engagement and taken the flag of Turkey to many countries. With this in mind, the Presidency for Turks Abroad and Related Communities (YTB) was established in 2010 to administer and expand Turkey's interaction with the world by giving scholarships and supporting the diaspora's relations with Turkey. ${ }^{8}$ YTB has reconstructed Turkish scholarships totally and established a truly sustainable system for the future. Since 2011, more than 16,000 students received Turkish scholarships from over 160 countries through YTB. ${ }^{9}$ Similarly, the Diyanet Foundation has opened international Imam-Hatip Schools in several Turkish cities and brought fully funded international students from the Muslim world into Turkey. While these institutions have strengthened Ankara's role as an educational soft power, their activities have been mostly limited to within Turkey. There was no separate institution responsible for managing education abroad until the establishment of Turkish Maarif Foundation.

Indeed, underlying Turkey's position as an international student destination, Ankara has always prioritized the policy of being a hub for international students. To mention a few, the major initiatives for the purpose of internationalization of education in Turkey were: Bologna process, student exchange programs, Turkey Scholarships Overseas Graduate Program Ministry of Education (Law No: 1416), TÜBITAK overseas research scholarships, Higher Education Council (YÖK) scholarships, etc. 


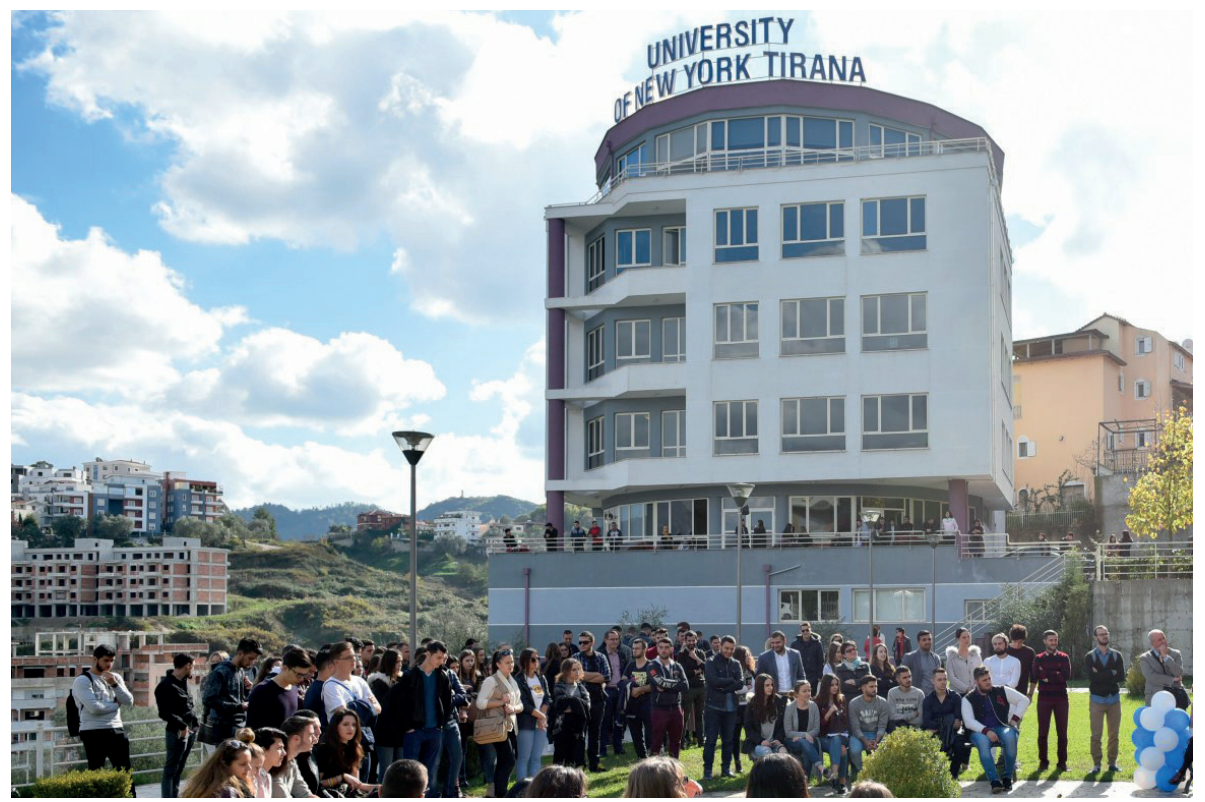

University of New York Tirana is a university managed by the Turkish Maarif Foundation in Albania.

Thanks to these initiatives, there has been a significant increase in the number of international students coming to Turkey in the last two decades. While the number of international students in Turkey was 5,300 in 1983, it has risen to 16,500 in $2000,55,000$ in 2013 and 150,000 in 2018. According to YÖK's strategic documents, ${ }^{10}$ this figure reached 160,000 in 2019; furthermore it is expected to be 178,000 at the end of 2020 and 200,000 at the end of 2021. The Turkish government expects the foreign students' body in Turkish universities to reach the level of 350,000 in 2023. Although the increase in numbers is already satisfactory, Turkey has the potential to host more international students.

It is estimated that around 4-5 million students worldwide choose another country for education. In 2017 alone, annual income for the United States from international students was $\$ 42.4$ billion $^{11}$, almost triple amount of Turkey's financial deficit in 2017 (\$12.9 billion). ${ }^{12}$ This global mobility in international education has been labeled as education tourism, due to its material return to the hosting countries.

\section{Turkish Maarif Foundation: Role, Scope, and Importance}

Law No. 6721 adopted by the Turkish Grand National Assembly established the Turkish Maarif Foundation as a public entity in June 2016. According to the law it was founded upon, the TMF exists to provide formal education on all levels, based on the universal values of humanity. It carries out activities at all levels of education including kindergarten and higher education. Within the framework of the law itself, TMF is desig- 
The educational activities of the Turkish Maarif Foundation should be seen as the concrete visibility and sustainability of Turkey's contribution to global development of its representatives, school administrators and teachers are aware of the fact that each of them is perceived to be a cultural ambassador in the host country they serve.

Turkish Maarif Foundation, while performing a cultural diplomacy mission, takes the example and guidance of Hoca Ahmet Yesevi, Mevlâna Celaleddin-i Rûmî, Yunus Emre, Hacı Bektaş-1 Veli, Hacı Bayram-1 Veli, Sarı Saltuk and others who were the pioneers of the Anatolian cultural tradition of inclusiveness, love to humanity and respect to differences. The symbol of the Anatolian carpet, which is also represented in the emblem of the Turkish Maarif Foundation, refers to TMF's understanding of encompassing civilization based on this love and solidarity.

There are also further reasons for the existence of TMF. Turkey is now an emerging actor and a rising star in the international arena. It cannot only rely on improving its economic relations with other countries; people-to-people relations are as important as intergovernmental relations to render the interactions between the countries, and education is seen as an important component of this integration process.

\section{Reclaiming Educational Soft Power}

Although established before the military coup attempt, the role of the Turkish Maarif Foundation became more critical after the July 15, 2016 bloody military coup attempt. Turkish foreign policy makers have focused on FETÖ-run schools all over the world. Either transferring them 
to Turkish governmental control or shutting them down has occupied the highest-level in the agenda in almost all meetings between Turkish leaders and their counterparts. In this process TMF was identified as the true address to which these schools should be transferred. Therefore, the TMF has expanded quickly in many countries either by undertaking the management of some former FETÖrun schools or opening new alternative schools and educational centers. However, it was primarily tasked with opening kindergarten, primary, secondary, and higher education institutions as well as establishing cultural centers, therefore, TMF is now focusing more on this original goal, which focuses on opening schools from scratch. As of January 2020, little more than 3 years since it was established, the Turkish Maarif Foundation has a very successful scorecard.

Acting as Turkey's international education agency, the Turkish Maarif Foundation, the youngest institution of Turkey to be active abroad, accomplished its organization within a short period of time. With its 51 offices worldwide, TMF now manages Turkey's international investments in education. TMF runs 323 schools at different levels, 42 dormitories and one university, in a total of 43 countries. As of January 2020, there are around 40 thousand students studying at Turkish Maarif Foundation's educational facilities. Out of those 323 schools, 213 of them have been taken over from FETÖ related groups, while the remaining have been opened by TMF. All of the ac- quired schools have been primarily managed through close cooperation with local educational authorities and monitoring by the Turkish Foreign Ministry. In some cases, such as in Pakistan, the constitutional court has declared FETÖ affiliated groups in the country as terrorist organizations and ordered its government to hand over all these schools to TMF. In the case of Afghanistan, an international agreement between the educational ministries provided the base for the transfer of the affiliated schools.

In the past, the brand of "Turkish schools" abroad was mostly used, popularized and even hijacked by FETÖ. TMF is effectively reclaiming educational soft power for Turkey. The Turkish Maarif Foundation is a state entity, but run autonomously by a 12-member board of trustees, of which 7 are appointed directly by the president and 5 come from different ministries as representatives. The budget is allocated as a yearly-based grant, open to governmental audit. As TMF deepens and expands its activities, it is likely that Turkey's brand in international education will be more visible in coming years.

\section{Deepening Internationalization of Education in Turkey}

Turkish Maarif Foundation serves to introduce Turkey and Turkish universities to the international community. In 2018, TMF organized three international education fairs in Sudan, Mali, and Tunisia. Nearly 30 universities and a total of 10,000 visitors participated in those fairs. In 2019, TMF continued its promo- 
tional activities with fairs in Albania and Iraq and for 2020 it has plans for organizing in 15 more countries.

TMF is also working on setting up a specifically dedicated international educational agency to promote educational opportunities in Turkey. This agency and the website prepared in accordance with the developments in international education mobility will provide both professional support services to the students who want to come to Turkey from abroad and Turkish universities will be introduced. TMF administrators expect the foundation to have a significant role in increasing the number of international students coming to Turkey with these fairs, promotions, agencies and web initiatives.

On the other hand, TMF has been working closely with Turkish universities to further internationalize education in Turkey. In this respect, TMF has signed a Memorandum of Understanding to encourage more universities to join international educational platforms. TMF has signed a memorandum with more than 40 universities and conducts, on their behalf, the Examination for Foreign Students (YÖS) in TMF offices in many countries. In a way, this and other activities, gives TMF a coordinating role between international students and Turkish universities.

\section{Meeting UN Millennium Development Goals}

The mission and activities of TMF are also in harmony with the objectives of 'Quality Education for Sustainable
Development' declared in the 2030 Vision Document of the United Nations. Through Maarif Schools children from all range of economic and social backgrounds can have the opportunity to obtain good quality education. Looking at the maps of Maarif Schools, it can be seen that most of the schools are located in third world countries, especially in the Least Developed Countries (LDCs). Since Turkey's opening to Africa in 2005, ${ }^{13}$ Ankara has a special commitment for LDCs in terms of development aid, social solidarity and political support. With the active role of TMF, Turkey has complimented the educational element to its support of LDCs.

Ankara has been eager to play its share in Millennium Development Goals. For example, Turkey became the highest spending country in the world in global humanitarian assistance for two years in a row in 2017 and 2018. Ankara spent $\$ 8.4$ billion in humanitarian assistance in 2018, while its aid expenses were $\$ 8.1$ billion in 2017 , according to the Development Initiative's (DI) Global Humanitarian Assistance Report. ${ }^{14}$ The educational activities of the Turkish Maarif Foundation should be seen as the concrete visibility and sustainability of Turkey's contribution to global development. Education and trade are two main means to influence and transform societies for good from within, without disrupting the existing structures.

\section{Developing a New Curriculum}

The Turkish Maarif Foundation attaches great importance to the preparation of specific training programs 
and curriculum. In this context, TMF believes in what is known as the GLONACAL (global, national, local) concept to be able to follow global developments with a special training model, which is equipped at the global level; but learns and absorbs national values specific to each country in which it operates. What is transnational in Maarif philosophy is that it focuses on education as the nurturing of a 'good person' with universal moral values, ethics and responsibilities. Wherever TMF has a school, it aims to educate a generation aware of their traditions, culture, and values so that they will not be alienated from their own people but rather to be raised as patriots who will commit themselves to the developmental struggle of their own nations while also being open to global cooperation. With this understanding, the Turkish Maarif Foundation prepares curricula for its students covering modern science, social sciences, technological skills, language skills (Turkish, local, and global languages), as well as an education in local culture and values. This is extremely important because it is an example of a model curricula developed by a non-western state. Similarly, it is a very good example of South-South development by transferring a southern perspective toward southern countries.

Another area in which TMF places much importance on the curriculum is teaching Turkish as a second language. Turkish Maarif Foundation considers teaching Turkish according to international standards and aims to have every student graduated from

\section{Turkey is also developing}

a new generation of international educators which will be an important element for the role of Turkey in international education and the future of Turkish Maarif Foundation itself

Maarif Schools with at least the skills to use a B2 level of Turkish. For this purpose, TMF's education department has developed a new Curriculum for Turkish Language Teaching as a Foreign Language. Within the scope of this Turkish curriculum, textbooks and educational materials are prepared and will be available in the first half of 2020.

All in all, international education is expanding horizontally and vertically. What makes a contribution to this field of education unique is to develop new curricula and innovative ways of teaching. Turkish Maarif Foundation aims to open new horizons in these areas while creating a healthy environment (both in terms of physical facilities and personal development) for education.

\section{Conclusion}

The Turkish Maarif Foundation is the latest actor in Turkish foreign policy in terms of its soft power. However, its 
impact, influence and imprint is likely to stay much longer than others. Education is the best way to transform any society positively and connect them with the world. This locates TMF at the heart of society-to-society relations that Turkey seeks with many countries. Turkey is also developing a new generation of international educators which will be an important element for the role of Turkey in international education and the future of Turkish Maarif Foundation itself.
To summarize the Turkish Maarif Foundation will continue to contribute to the internationalization of education in Turkey by widening its horizons in the field of education and bringing different experiences to Turkey. Similarly, TMF as an organization has aspirations to be more than just an educational institution abroad by making a very significant contribution to Turkey's overall foreign policy in terms of cultural and educational diplomacy.

\section{TURKISH MAARIF FOUNDATION IN THE WORLD}

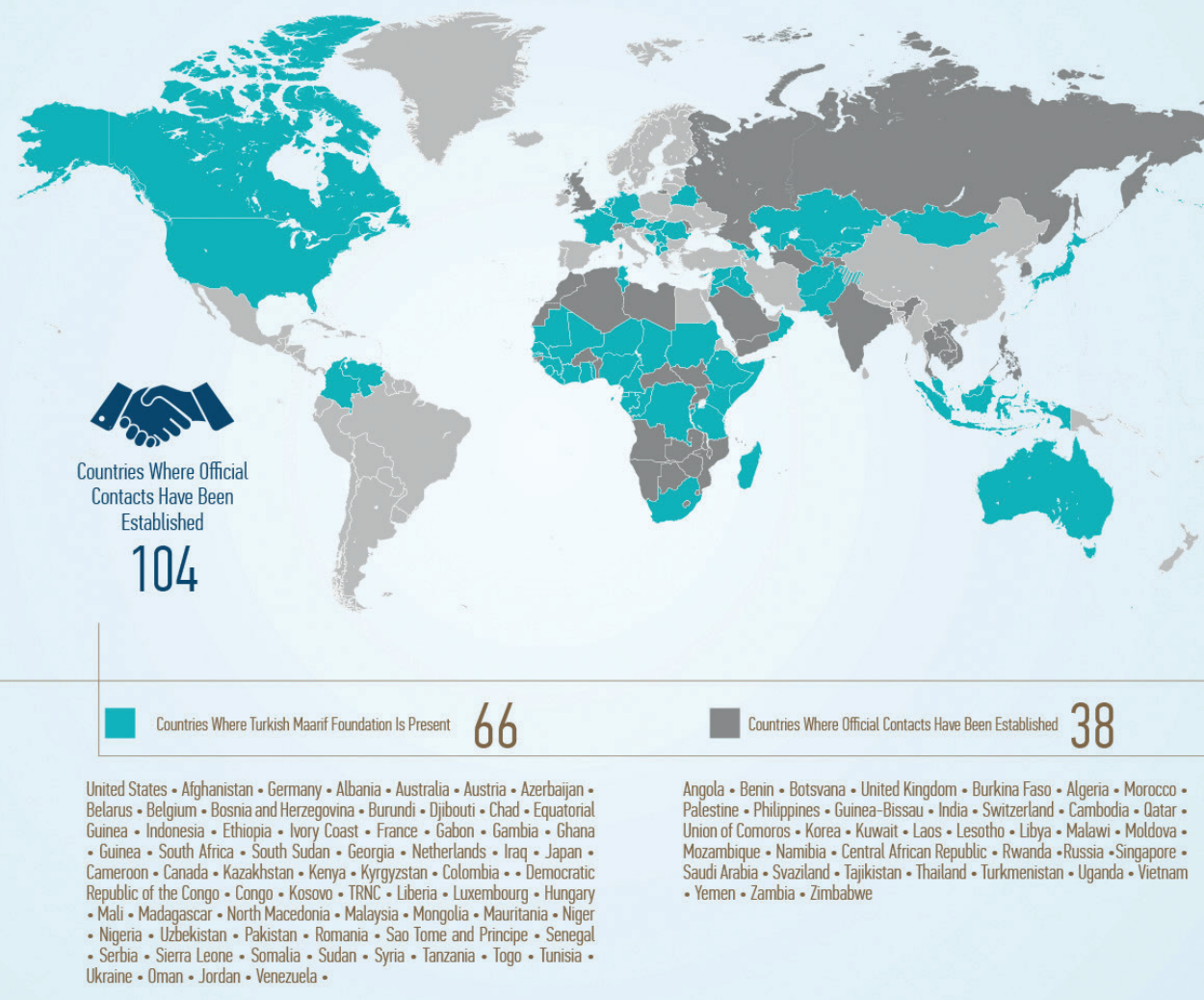




\section{CURRENT SITUATION}

\section{FEBRUARY 2020}

\begin{tabular}{|c|c|c|}
\hline Country & $\begin{array}{l}\text { Educational } \\
\text { Institutions }\end{array}$ & Dorm \\
\hline USA & 4 & - \\
\hline Afghanistan & 42 & 12 \\
\hline Germany & 1 & \\
\hline Albania & 6 & - \\
\hline Austria & 1 & - \\
\hline Australia & 2 & - \\
\hline Belarus & 1 & - \\
\hline Belgium & 1 & - \\
\hline Bosnia and Herzegovina & 4 & - \\
\hline Burundi & 2 & - \\
\hline Djibouti & 2 & - \\
\hline Chad & 6 & 1 \\
\hline Equatorial Guinea & 4 & - \\
\hline Ethiopia & 4 & 1 \\
\hline Côte d'lvoire & 4 & $\cdot$ \\
\hline France & 1 & - \\
\hline Gabon & 4 & - \\
\hline Gambia & 3 & - \\
\hline Ghana & 1 & - \\
\hline Guinea & 10 & 2 \\
\hline Georgia & 4 & - \\
\hline Iraq & 10 & - \\
\hline Cameroon & 14 & 4 \\
\hline Congo & 4 & - \\
\hline Dem. Rep. of Congo & 4 & - \\
\hline Kosovo & 8 & - \\
\hline Northern Macedonia & 5 & 1 \\
\hline Hungary & 1 & - \\
\hline Madagascar & 3 & - \\
\hline Mali & 21 & 1 \\
\hline Mauritania & 9 & - \\
\hline Niger & 10 & 2 \\
\hline Pakistan & 77 & 11 \\
\hline Romania & 6 & - \\
\hline Sao Tome and Principe & 1 & - \\
\hline Senegal & 13 & - \\
\hline Sierra - Leone & 2 & - \\
\hline Somalia & 7 & 3 \\
\hline Sudan & 6 & - \\
\hline Tanzania & 6 & 2 \\
\hline Tunisia & 4 & 1 \\
\hline Jordan & - & 1 \\
\hline Venezuela & 5 & - \\
\hline Total & 323 & 42 \\
\hline
\end{tabular}

\section{$\diamond$ turkiyemaariforg}

\section{Endnotes}

1. Maarif means education, knowledge, culture, system of education, and wisdom altogether.

2. Mostly known in the West as Gülen Movement, since July 15,2016 , this group is declared as FETÖ terrorist group by Turkish authorities as well as Gulf Cooperation Countries and OIC member states. "Organization of Islamic Cooperation Declares FETÖ a Terrorist Group", Daily Sabah, (October 9, 2016), retrieved from https:// www.dailysabah.com/war-on-terror/2016/10/19/ organization-of-islamic-cooperation-declares-feto-a-terrorist-group. 
3. Mary Hayden, "Transnational Epaces of Education: The Growth of the International School Sector", Globalisation, Societies and Education, Vol. 9, No. 2 (2011), pp. 211-224.

4. "International Education in Great Demand," ISC Research, (2013) quoted in Alexander Gardner McTaggart, "International Elite, or Global Citizens? Equity, Distinction and Power: The International Baccalaureate and the Rise of the South", Globalisation, Societies and Education, Vol. 14, No. 1 (2016), p. 10.

5. "Is China both a Source and Hub for International Students?" China Power, retrieved from https://chinapower.csis.org/china-internationalstudents/.

6. "In the Developing World, India Is a Major Hub for Foreign Students" Huffington Post, (March 31, 2017), retrievedfromhttps://www.huffingtonpost. in/2017/03/31/in-the-developing-world-india-isa-major-hub-for-foreign-studen_a_22020122/.

7. "Yurt Dışı Okullarımız," Republic of Turkey Ministry of National Education, (January 2019), retrieved from https://yyegm.meb.gov.tr/www/ yurt-disi-okullarimiz/icerik/366.

8. "Institution," Presidency for Turks Abroad and Related Communities, retrieved from https://test.ytb. gov.tr/en/corporate/institution.
9. Retrieved from https://www.turkiyeburslari. gov.tr/tr/sayfa/hakkimizda/turkiye-burslari.

10. "Yükseköğretimde Uluslararasılaşma Strateji Belgesi," Higher Education Council, (June 30, 2017), retrieved from https://www.yok.gov. tr/Documents/AnaSayfa/Yuksekogretimde_ Uluslararasilasma_Strateji_Belgesi_2018_2022. pdf.

11. "Number of International Students in the United States Reaches New High of 1.09 Million," retrieved from https://www.iie.org/Why-IIE/Announcements/2018/11/2018-11-13-Number-ofInternational-Students-Reaches-New-High.

12. "Turkey Posts Nearly $\$ 13$ Billion in Annual Budget Deficit", Hurriyet Daily News, (January 15, 2018), retrieved from https://www.hurriyetdailynews.com/turkey-posts-nearly-13-billion-in-annual-budget-deficit-125770.

13. Mehmet Özkan and Birol Akgün, "Turkey's Opening to Africa," Journal of Modern African Studies, Vol. 48, No. 4 (2010), pp. 525-546.

14. Gökhan Ergöçün, "Turkey Remains Most Generous Donor of Humanitarian Aid," Anadolu Agency, (September 30, 2019), retrieved from https://www.aa.com.tr/en/world/turkey-remains-most-generous-donor-of-humanitarian-aid/1597587. 

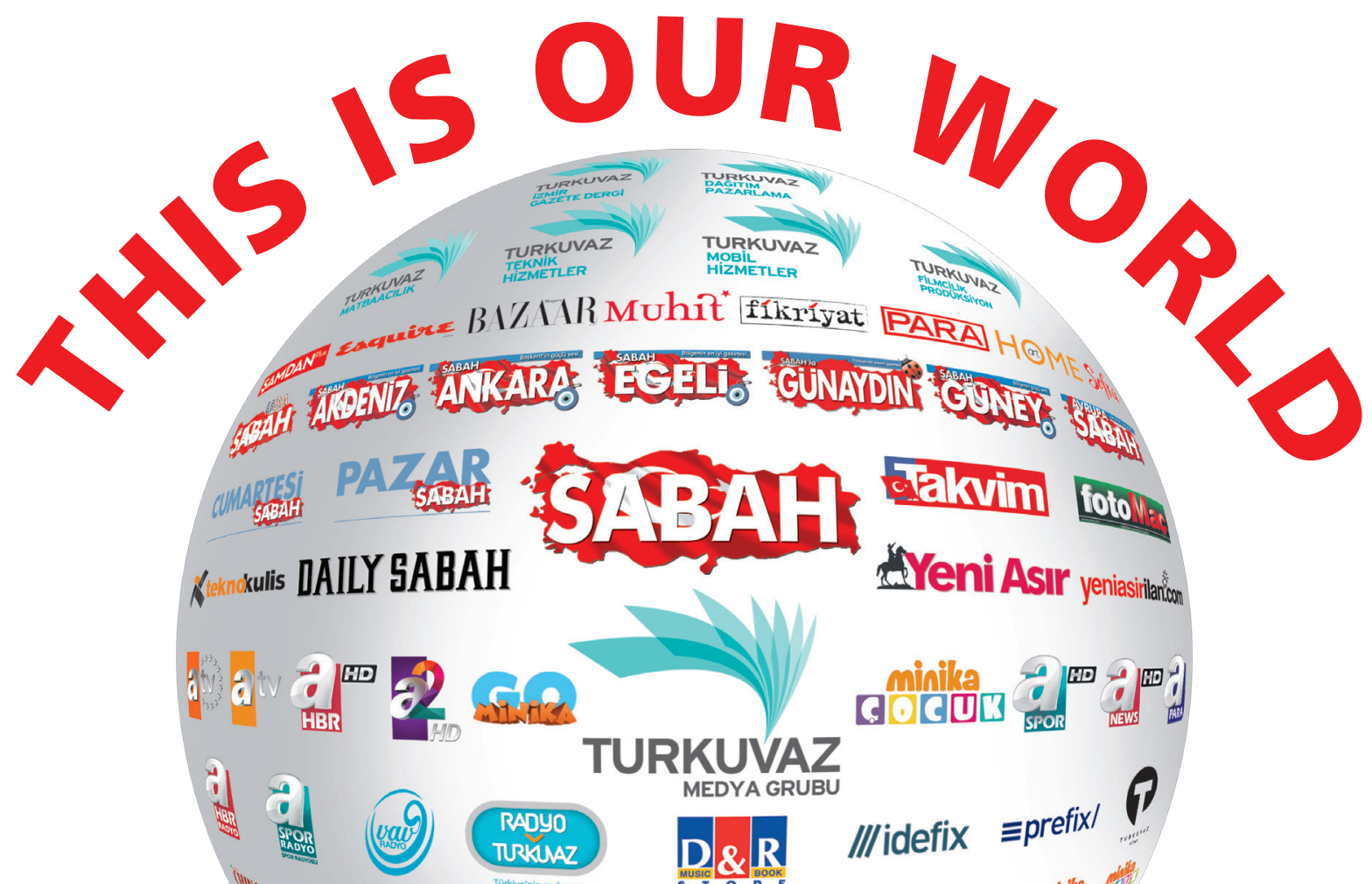

D. \& $\mathbf{R} \quad$ I/lidefix $\equiv$ prefix/

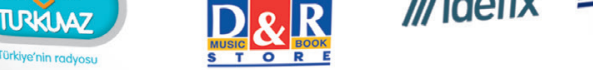

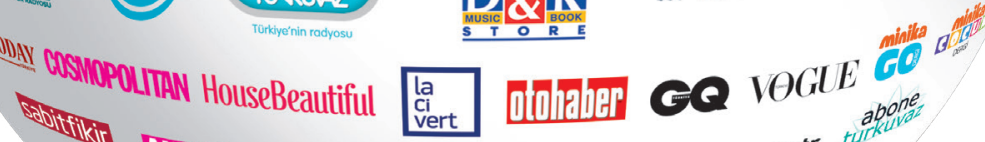

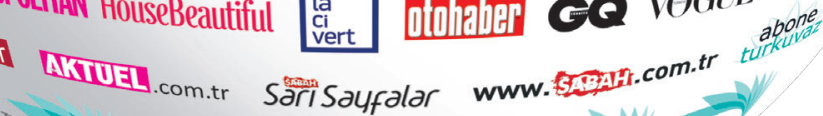

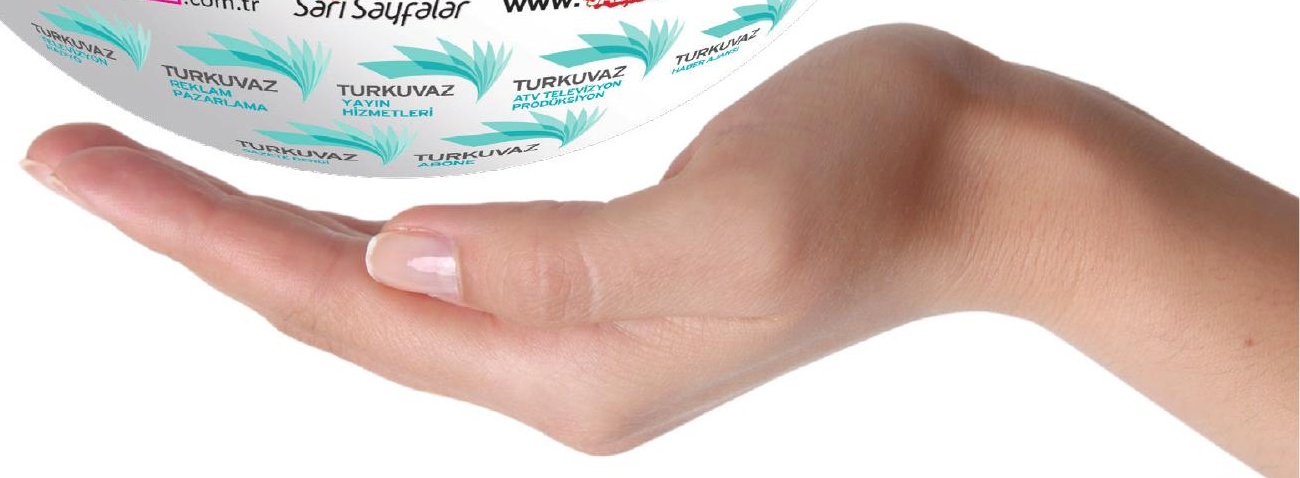

Turkuvaz Media Group is the leading group of companies which deals with broadcasting, publishing and distribution activities in Turkey. Most reputable national and international magazines, best selling local and national newspapers and prestigious tv channels create the most powerful synergy in Turkish media.

The opportunity to utilize this power for your advertisements is in your hands. Why not use it? 